\title{
VOLCANIC AND VOLCANICLASTIC FEATURES IN ARCHEAN ROCKS AND THEIR TECTONIC ENVIRONMENTS, RIO DAS VELHAS GREENSTONE BELT, QUADRILÁTERO FERRIFERO, MG - BRAZIL
}

\author{
MARCIA ZUCCHETTI ${ }^{1}$,LYDIA M. LOBATO ${ }^{2}$ AND ORIVALDO F. BALTAZAR ${ }^{1}$
}

\begin{abstract}
Rocks of Rio das Velhas Greenstone Belt subject of this paper are contained within the Quadrilátero Ferrifero region, Minas Gerais State, in the southeastern portion of Brazil. Volcanic rocks are represented by komatiites, basalts, andesites, dacites and volcaniclastic rocks, metamorphosed under greenschist facies. Despite intense deformation, these rocks preserve some original textural features like spinifex, variolitic, porphyritic and ophitic. Quench textures, pillow lavas and chemical sediments association (iron formation and metachert) indicate an ocean environment for mafic-ultramafic flows. The basalts geochemical patterns indicate that at least part of them formed from a mantle plume. The felsic volcanic and volcaniclastic rocks association indicates a subaerial explosive volcanism in an island-arc type environment.
\end{abstract}

Keywords:

INTRODUCTION Rocks of the Rio das Velhas Supergroup compose one of the most important Archean greenstone-belt successions in Brazil in view of its extensive mineral production and potential. A large part of the Rio das Velhas Greenstone Belt (RVGB) is contained within the Quadrilátero Ferrifero (QF) region, Minas Gerais State, located in the southeastern portion of the country. QF occupies the southernmost part of the São Francisco craton (Almeida 1976, Almeida \& Hasui 1984). The craton is bounded by Brasilianoage $(0.75$ to $0.45 \mathrm{Ga})$ mobile belts, and was consolidated during the Archean and Palaeoproterozoic.

Most rocks of the RVGB are intensely deformed by early Archean and later Paleo- to Mesoproterozoic deformations (Baltazar et al. 1994). Besides, since parts of the QF are at the craton boundary in its easternmost sector, EW-trending structures typical of the Neoproterozoic mobile belts are superimposed on, and modify, earlier structures. This has led structural and tectonic researchers to turn their attention to this rather complex evolutionary history (e.g. Chemale et al. 1994). Most workers discuss the structural evolution of greenstone rocks based almost exclusively ori gold mineralized areas (e.g. Vieira \& Oliveira 1988). These areas occupy principally the central sector of the $\mathrm{QF}$ and are the most deformed in the whole terrain. On the other hand, on a regional scale the discussion has focused mainly on the younger, Transamazonian erogenic imprint. This has influenced the concept that the RVGB-QF rocks preserve very little of their original textural attributes.

More recently, Baltazar \& Pedreira (1998), Silva (1998), Zucchetti (1998), Zucchetti et al. (1998a) and Zucchetti \& Lobato (1999) show that some of the metavolcanic and metasedimentary rocks of the greenstone succession preserve extraordinary original features, just like other greenstone belts in the worldwide as Abitibi and Belingwe greenstone belts.

STRATIGRAPHY The geological units of the QF include (1) TTG gneiss terranes of Archean age, (2) Archean greenstone belts of the Rio das Velhas Supergroup, and related successions, and (3) Paleo- and Mesoproterozoic, sedimentary units of the Minas Supergroup, the Itacolomi Group and the Espinhago Supergroup (Dorr 1969, Noce et al. 1996, and references therein).

Dorr et al. (1957) define the Rio das Velhas Series, which is subdivided into the Nova Lima and Maquine Groups. The latter is further subdivided into the basal Palmital (O'Rourke, In Dorr 1969) and the top Casa Forte (Gair 1962) Formations. Lockzy \& Ladeira (1976) propose the present Rio das Velhas Supergroup denomination. It is later described as a metavolcano-sedimentary, greenstone belt succession (Almeida 1976 and Schorscher 1976), of greenschist facies. Baltazar \& Pedreira $(1996,1998)$ and Pedreira \& Silva (1996) group the rocks of the Rio das Velhas Greenstone Belt (RVGB) in genetically related lithofacies associations (Fig. 1). These associations based the lithostratigraphic subdivision set forward by Zucchetti et al. (1996, 1998a).

Nova Lima Group From base to top, the Group encompasses the Volcanic Mafic-ultramafic, Volcanic, Clastic- and Chemicalsedimentary, Volcaniclastic, and Resedimented Associations.
The Volcanic Mafic-Ultramafic Association is composed of komatiitic and tholeiitic lava flows, subordinate intrusive gabbros, anorthosites and peridotites. Metamorphosed banded iron formation (BIF), ferruginous chert, mafic tuffs, felsic volcaniclastic rocks and carbonaceous schist are intercalated.

The Volcanic, Clastic- and Chemical-Sedimentary Association is made up of volcanic and sedimentary (chemical and clastic) rocks. It is divided into volcano-chemical and clastic-chemical groups. The former is characterized by tholeiitic and komatiitic basalts intercalated with abundant BIF, ferruginous chert and carbonaceous phyllite. The clastic-chemical group is typified by fine-grained, carbonaceous phyllite associated with BIF and ferruginous metachert.

The Volcaniclastic Association comprises felsic and mafic volcaniclastic rocks. A lithofacies with polymictic and monomictic breccias and another with conglomerate-sandstone are recognized. Dacitic flows are subordinate, and occur as lenses intercalated in basalt.

The Resedimented Association consists of a succession of graywacke and argillite-graywacke cycles, which represent turbidites deposited in a submarine environment. In the south part of RVGB-QF, the graywacke-argillite successions are carbonate-rich, and exhibit calc-silicate rocks and polymictic conglomerate.

Maquine Group From bottom to top, the Group encompasses the Palmital (Coastal Association) and Casa Forte Formations (NonMarine Association).

The Coastal Association contains three main lithofacies: (i) mica quartzites with ripple marks; (ii) quartzites displaying herringbone and tabular cross-bedding; (iii) quartzites displaying tabular cross-bedding. They characterize a coastal environment, with tidal plains and coastal dunes.

The Non-Marine Association is represented by two lithofacies: the polymictic conglomerate-sandstone and microconglomeratic sandstone. Polymictic conglomerates are interpreted as longitudinal bars. Sandstones are interpreted as linguoid bars, upper flow regime bar top sands and channel-fill deposits. The sandstonemicroconglomeratic lithofacies is related to a braided-river fluvial system (Baltazar et al. 1994).

VOLCANIC AND VOLCANICLASTIC FEATURES OF THE RVGB-QF ROCKS The rocks under study display mineral associations typical of the greenschist facies (actinolite + albite + chlorite + epidote).

Schorscher (1978) describes komatiites in the RVGB-QF for the first time. Komatiites compose the base of volcanic pile, which also contains subordinate BIF, chert, tourmalinite and carbonaceous pelite. They are subaqueous, peridotitic komatiites (Sichel 1983), forming massive or pillowed, and locally brecciated flows, with spinifex texture. Schrank et al. (1990) recognize the following characteristics typical of komatiitic flows: spinifex texture, cumulus olivine with intercumulus orthopyroxene and a level of lahar-type breccia.

Basalts are represented predominantly by fine-grained actinolite schists, occurring in pillowed and massive flows. Pillowed basaltic lavas are described for the first time by Ladeira (1981). Zucchetti

1 - CPRM - Geological Survey of Brazil, Av. Brasil 1731, Funcionários, 30140-002, Belo Horizonte, MG, cprmnels@estaminas.com.br 


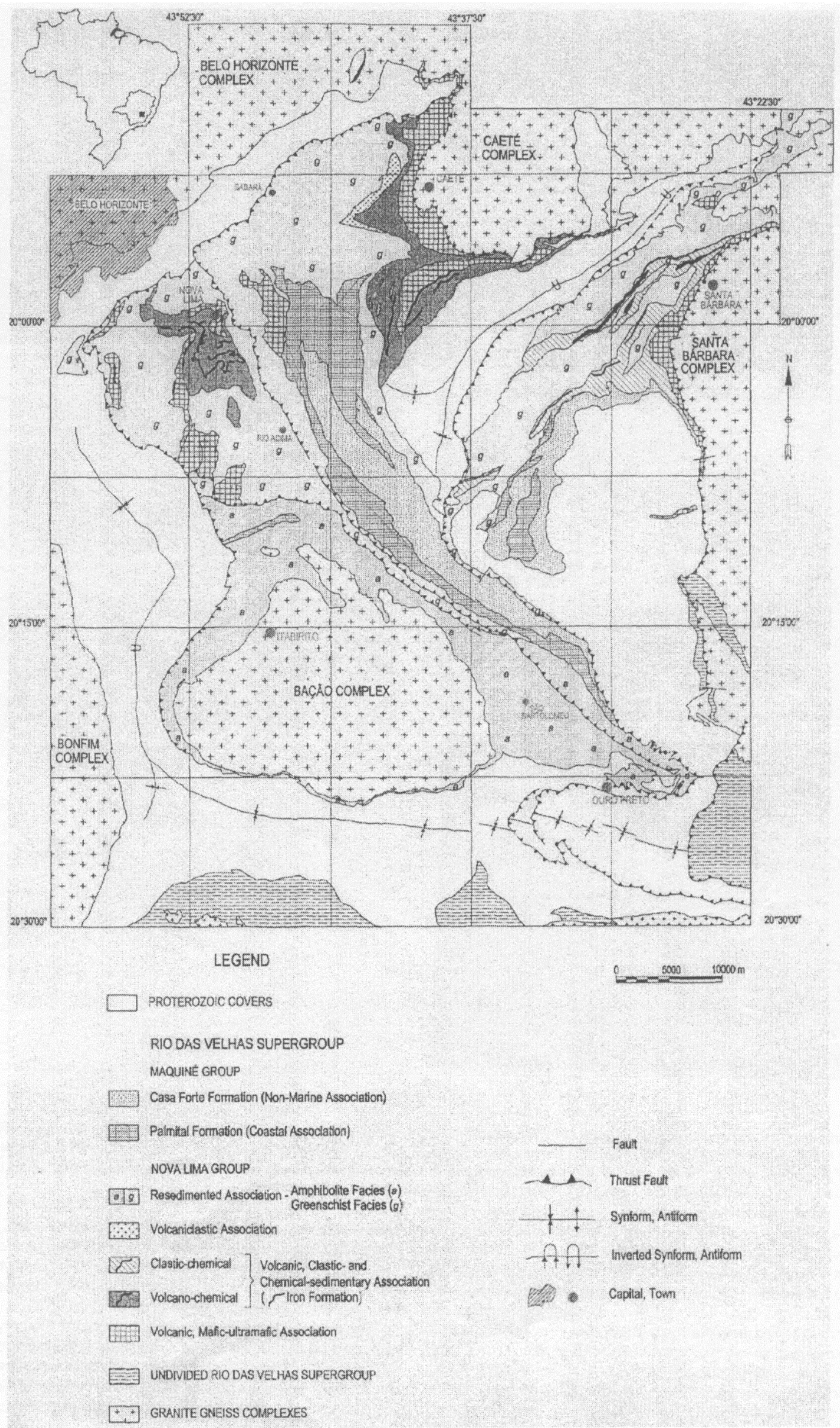

Figure 1 - Geological map of the Rio das Velhas Supergroup. Modified from Baltazar \& Silva (1996) and Baltazar \& Pedreira (1996). 

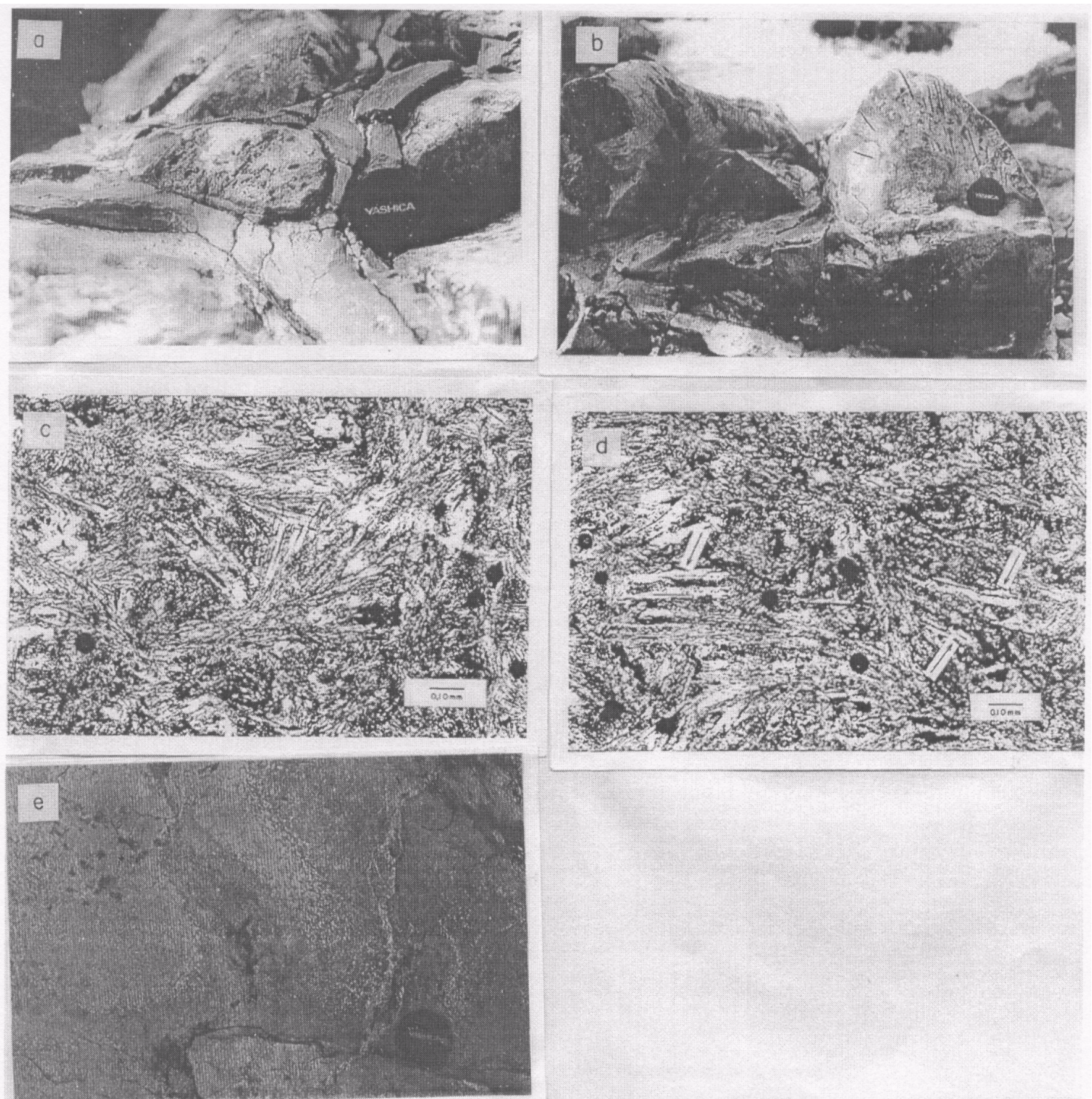

Figure 2 - Metabasalts textural and structural features: a) pillowed metabasalt displaying small-sized pillow at the triple junctions of larger pillows; b) pillow lava exhibiting radial quench joints (highlighted in black) and external quench crust (to the right of the pillow); c) metabasalt with fan texture, characterized by intercalated plagioclase and actinolite needles, plane-polarized light; d) metabasalt with plagioclase crystals containing hollow cores (arrows), planepolarized light; e) variolitic metabasalt, the varioles (in white) coalesce and imprint irregular patches.

(1998) and Zucchetti et al (1998b) divide basalts into tholeiites and magnesian tholeiites, the former with $\mathrm{MgO}<9 \%$ and the latter with $\mathrm{MgO}$ between $9 \%$ and $14 \%$. The pillows vary from approximately 30 to $40 \mathrm{~cm}$, and are locally smaller $(\sim 15 \mathrm{~cm})$ along triple junctions of larger pillows (Fig. 2a). The pillows exhibit homogeneous, microgranular core. The borders have radial and concentric quench zones, amigdules and an external quench crust (Fig. 2b).

Deformation caused amigdules to be lenticular (1 to $5 \mathrm{~mm}$ ). Amigdules formed from vesicles filled with minerals deposited directly from gases or solutions (Barker 1983). They now contain quartz, carbonate, opaque minerals, albite, epidote and chlorite in variable amounts and sizes that are larger than the grains in the matrix. Plagioclase preserves its tabular habit, Albite and Carlsbad twinning planes and two quench features: fan texture and hollow cores. The former is shaped by plagioclase and actinolite needles, crystallized from a single nucleation point (Fig. 2c). The latter is characterized by a very fine-grained material, possibly epidote, covering the originally hollow, central portion of some crystals (Fig. 2d).

The massive basaltic lavas have a globular feature, in which both globule and matrix have the same mineralogical composition and different sizes. The globule has larger crystals and the matrix encloses it with finer crystals oriented along their margins. One hypothesis is that the globules would have formed due to differences in magma viscosity.

Some medium-grained lava flows have ophitic/subophitic texture, with randomly oriented tabular albite crystals partially to completely 

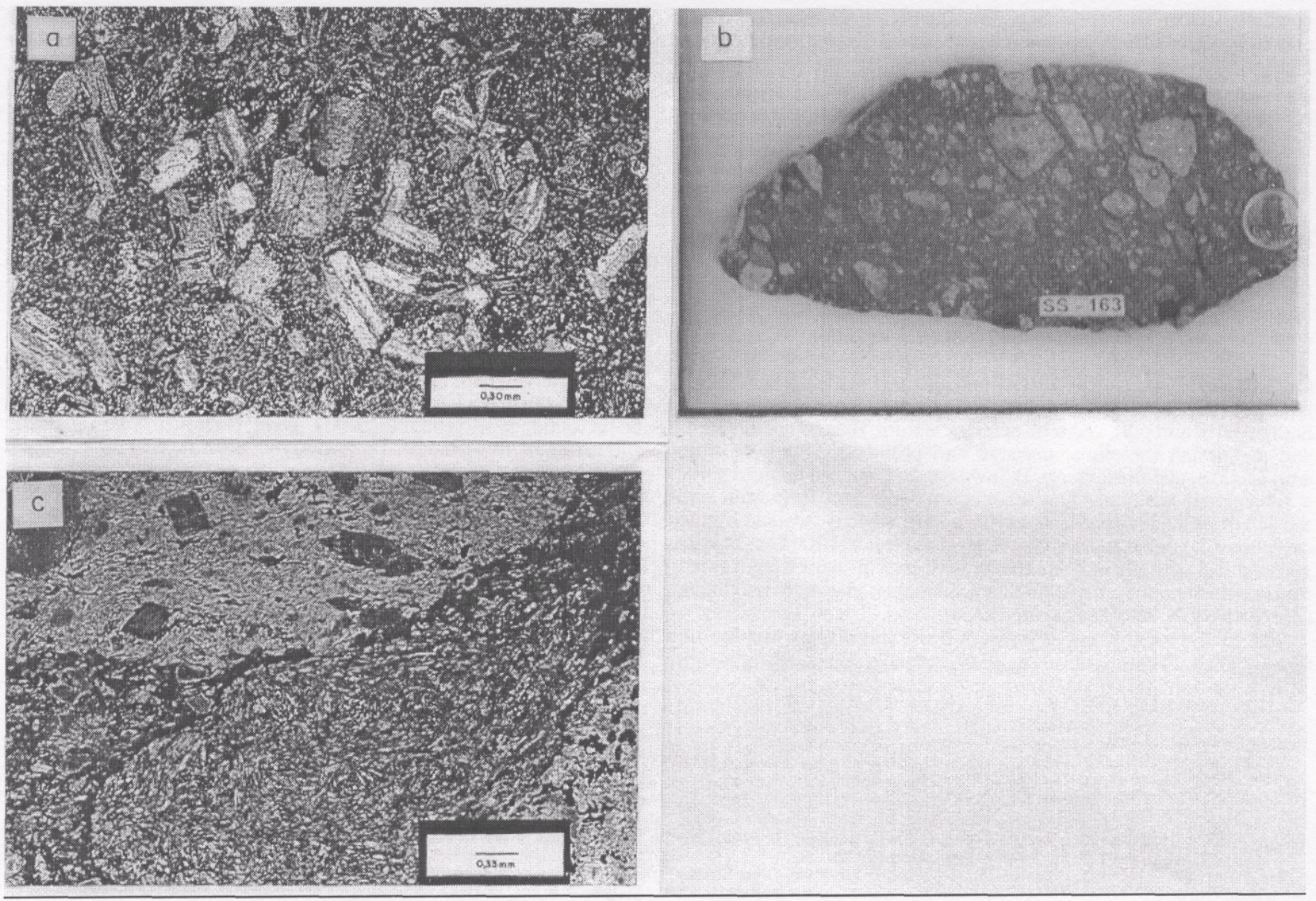

Figure 3 - Volcanic and volcanidastic textural and structural features: a) metadacite exhibiting porphyritic texture, composed of euhedral plagiodase phenocrysts, crossed polarizers; b) volcanidastic, monomictic breccia containing dacite clasts; c) volcanidastic, polimictic breccia containing dacite (upper part) and basalt (lower part) clasts, plane-polarized light.

included in amphibole. Quartz is locally skeletal and has optical orientation displaying micrographic intergrowth with plagioclase. This may represent a feature inherited from magma crystallization. Where well crystallized, tholeiitic basalts may display micropegmatitic portions or micrographic texture (Morse 1994). Dimroth \& Lichiblau (1979) describe micrographic intergrowth between plagioclase and quartz in both pillowed and massive Archean volcanic rocks, interpreting it as an igneous feature. Alternatively, this feature can be interpreted as devitrification (Barker 1983). However, since basalts exhibit granophiric texture the latter hypothesis is not favored.

Ladeira (1981) was the first to describe the existence of variolitic basalts in the RVGB, a feature common to magnesian tholeiites. The varioles occur as lenses elongated by deformation (1 to $8 \mathrm{~mm})$, which are parallel to the foliation and may coalesce forming irregular spots (Fig. 2e). There are no marked compositional variations between varioles and host rock, both composed of actinolite, clinozoisite, albite and quartz. Plagioclase needles, often branching, are replaced by albite and quartz and show a fan-like arrangement with amphibole in the interstices. The contacts between varioles and host rock are sharp, although amphibole needles may overcome the varioles margins.

The main hypotheses for a magmatic origin for the varioles include 1) quenching of magma of a uniform basaltic composition (Laurent \& Hebert 1975, Hughes 1977); 2) immiscibility of liquids of contrasting compositions (Gelinas et al. 1976). For the Nova Lima Group variolitic basalts, Zucchetti (1998) suggests that these features were originated from quenching of a single basaltic magma because the same mineral composition is present in both varioles and host rock. This is confirmed by the same chemical composition of actinolite inside and outside the varioles (Zucchetti 1998). The proposition of an origin from liquid immiscibility emphasizes the compositional contrast between varioles and the matrix, resulting in distinct rocks. Gelinas et al. (1976) affirm that skeletal crystals cutting across the boundaries between host rockvarioles would have crystallized simultaneously from two liquids. According to Philpotts (1997), however, crystals cutting across varioles-matrix boundaries does not itself poses a restriction to the single magma crystallization hypothesis, as long as the contacts are developed after the formation of crystals. So, since some actinolite crystals cross the varioles limits does not support the liquid immiscibility origin. In the samples studied, both matrix and varioles have similar textural characteristics, favoring its origin from magmatic processes related to quenching during their extrusion.

The acid lavas have a dacitic composition (Silva 1996, 1998), are massive and display porphyritic texture (Fig. 3a). Plagioclase is the predominant phenocryst, with a maximum size of $1.5 \mathrm{~mm}$ in a seriated texture. It is euhedral, generally short and stubby, sericitized, being similar to that described by Condie (1981). Phenocrysts of mafic minerals are secondary, with short hornblende prisms attaining a maximum of $1.2 \mathrm{~mm}$. Quartz is subordinate, occurring in microphenocrysts of approximately $0.45 \mathrm{~mm}$. Quartz phenocrysts rarely display corrosion features and partially preserved hexagonal sections. The matrix is composed of granoblastic quartz and plagioclase, and oriented sericite and chlorite plates that mark the rock foliation. The quartzo-feldspathic matrix results from the devitrification and recrystalization of original acid matrix. It represents the granophiric devitrification stage (Cas \& Wright 1988), which is characterized by fine-grained, recrystallized and equidimensional quartz and feldspar aggregates. Amigdules measuring up to $1 \mathrm{~mm}$ filled by granoblastic quartz and/or carbonate are locally present.

The volcanidastic rocks are represented by monomictic and polimictic breccias. The monomictic breccias have a sandy matrix 
containing dacite fragments (Fig. 3b). The polimictic breccias have a clay-rich matrix with fragments of basalt and dacite (Fig. 3c). Both are matrix-supported with predominantly angular, poorly selected, decimeter- to millimeter-sized fragments. Lenticular shapes are common due to deformation. The matrix of monomictic breccias is texturally and compositionally similar to its fragments and to the associated dacitic lavas. It displays larger plagioclase clasts ( 0.3 to 1.5 $\mathrm{mm}$ ) that preserve a tabular habit and complex igneous twinning; quartz and amphibole are subordinate. The matrix of polimictic breccias has a mafic composition, containing plagioclase, amphibole and epidote. The felsic fragments are texturally and compositionally identical to the associated dacitic lavas. The small and sparse fragments of basalt and dacite are aphanitic and composed of amphibole and plagioclase exhibiting quench texture.

CONCLUSIONS The RVGB volcanism is made up komatiites, basalts, andesites (e. g. Vieira 1991) and dacites. Kpmatiite flows are both massive and pillowed with spinifex texture. Basalts are tholeiites and magnesian tholeiites, massive and pillowed, with variolitic, amigdaloidal, and fan textures. Pillow lavas and quench textures show a subaqueous ambient. The association with iron formation and metachert indicates an ocean environment, what is stressed by the evidence of spilitization of basalts (Ladeira 1980). The basalts geochemical patterns indicate that at least part of them were formed from a mantle plume, characterizing a submarine plateau environment (Zucchetti 1998, Zucchetti et al. 1998b).

The dacitic rocks occur as massive flows and display porphyritic texture. The acid composition suggests explosive volcanism, although pyroclastic and autoclastic deposits have not yet been discovered. Its association with alluvial fan and stream-channel deposits and the existence of correlated volcaniclastic deposits of fluvial environment, probably braided rivers, suggests an aerial environment for the acid volcanism. However, direct evidence is lacking. The andesitic and dacitic rocks indicate that an island-arc and probably a back-arc environment took place in the greenstone evolution, after the maficultramafic flows.

The volcaniclastic lithofacies are composed of sedimentary breccias and conglomerate-sandstone successions, associated with dacitic flows. Breccias' matrix and fragments are texturally and compositionally identical to the associated dacitic lavas. They are recognized as debris-flow deposits (lahars) and the conglomeratesandstone successions as stream-channel deposits. This association is therefore interpreted as alluvial-fan deposits very near to the source, next to the volcanic cone escarpment in an island-arc environment. Although direct evidence of the existence of pyroclastic rocks have not been found, it is probable that a good portion of the epiclastic fragments of this association is derived from erosion of tuffs and agglomerates.

Acknowledgements To Departamento Nacional da Produção Mineral (DNPM) for allowing the use of data pertaining to the Rio das Velhas Project, and CPRM-SUREG/BH for the support, to Augusto J. Pedreira and Wilson Wildner and two anonymous referees of RBG for suggestions to the manuscript. Continuing bursary support from $\mathrm{CNPq}$ is acknowledged by the second author.

\section{References}

Almeida F.F.M. de 1976. Estruturas do Pré-Cambriano Inferior Brasileiro. In: SBG, Congresso Brasileiro de Geologia, 29, Ouro Preto, Abstracts, 201-202

Almeida F.F.M. \& Hasui Y. 1984. O Pré-Cambriano do Brasil. São Paulo, Edgar Blucher Ltda.,378p.

Baltazar O.F., Correa Neto A.V., Silva S.L., Zucchetti M., Carvalho J.B., Raposo F.0.1994. Uma tentati va preliminar de aplicacão da estratigrafia de seqiuências ao Greenstone Belt Rio das Velhas, Quadrilátero Ferrífero (MG). In: SBG, Congresso Brasileiro de Belt Rio das Velhas, Quadrilátero Ferrifero (MG). In: SBG, Con
Geologia, 38. Balneario Camboriu, Expanded Abstracts, 1:82-83

Baltazar O.F. \& Silva S.L. da 1996. Projeto Rio das Velhas:Mapa Geologico Integrado do Supergrupo Rio das Velhas, escala 1:100.000, Belo Horizonte, DNPM/CPRM

Baltazar O.F. \& Pedreira A.J. 1996. Associações de litofácies. In: CPRM. Projeto Rio das Velhas: Texto Explicativo do Mapa Geológico Integrado, escala 1:100.000, Belo Horizonte, DNPM/CPRM, 43-48

Baltazar O.F. \& Pedreira A.J. 1998. Associações de litofacies. In: M. Zucchetti \& O.F. Baltazar (org.). Projeto Rio das Velhas: Texto Explicativo do Mapa Geologico Integrado, escala 1:100.000,2 ed. Belo Horizonte, DNPM/CPRM, 43-47

Barker D.S. 1983. Igneous Rocks. New Jersey, Prentice-Hall, 417 p.

Cas R.A.F. \& Wright J.V. 1988. Volcanic Successions. London, Unwin Hyman, 528 p.

Chemale Jr. F., Rosiere C.A., Endo 1.1994. The tectonic evolution of the Quadrilatero Ferrífero, Minas Gerais, Brazil. Precambrian Research, 65:25-54

Condie K.C. 1981. Archean Greenstone Belts. Amsterdam, Elsevier, 433 p.

Dimroth E. \& Lichiblau A.P. 1979. Metamorphic evolution of Archean hyaloclastites, Noranda area, Quebec, Canada. Part I: Comparison of Archean and Cenozoic seafloor metamorphism. Canadian Journal of Earth Sciences, 16:1315-1340

Dorr II J.V. 1969. Physiographic Stratigraphic and Structural Development of the Quadrilatero Ferrifero, Minus Gerais. U. S. Geological Survey Professional Paper. 614-A $110 \mathrm{p}$.

Dorr II J.V., Gair J.E., Pomerene J.B., Rynearson G.A. 1957. Revisão da estratigrafia precambriana do Quadrilátero Ferrifero: Brasil, DNPM-DFPM, 31 p. (Avulso 83)

Gair J.E. 1962. Geology and ore deposit of the Nova Lima and Rio Acima Quadrangles, Minas Gerais, Brazil. U. S. Geological Survey Professional Paper. 341-A, 67 p.

Gelinas L, Brooks C, Trzcienski W.E. 1976. Archean variolites-quench immiscible liquids. Canadian Journal of Earth Sciences, 13:210-230

Hughes C.J. 1977. Archean variolites-quenched immiscible liquids: Discussion. Canadian Journal of Earth Sciences, 14:137-139

Ladeira E.A. 1980. Metalogenesis of Gold at the Morro Velho Mine, and in the Nova Lima District, Quadrilátero Ferrifero, Minas Gerais, Brazil. University of Western Ontario, London, Ontario, Canada, Ph D. Thesis, 272 p.

Ladeira E.A. 1981. Primeiras lavas com almofadas pillows encontradas no Supergrupo Rio das Velhas, de idade arqueana, no Quadrilátero Ferrífero e no distrito de Pitangui, Minas Gerais. Ciencias da Terra, 1:122-14

Laurent R. \& Hebert Y. 1977. Features of submarine volcanism in ophiolites from the Quebec Appalachians. In: W.R.A. Baragar L.C., Coleman J.M. Hall H. (ed.) Volcanic regimes in Canadá, Ontario. The Geological Association of Canad Special Paper Number 16,91-109

Loczy L. de \& Ladeira E.A. 1976. Geologia Estrutural e Introdução a Geotectonica. São Paulo, Edgar Blucher Ltda./CNPQ, 528 p.

Morse S.A. 1994. Basalts and phase diagrams: an introduction to the quantitative use of phase diagrams in igneous petrology. Malabar, Krieger, $493 \mathrm{p}$.

Noce C.M., Carneiro A.M., Machado M., Texeira W. 1996 Late Archean granitoids of the Quadrilátero Ferrifero region: U-PB geochronology and implications on crustal evolution. In: SBG, Symposium of Archean Terranes of the South American Platform, Ouro Preto, Extended Abstracts, 60-61
Pedreira A.J. \& Silva S.L. 19\%. Sistemas deposicionais do Greenstone Belt Rio das Velhas, Quadrilátero Ferrifero, Minas Gerais. In: SBG, Congresso Brasileiro de Geologia, 39. Salvador, Anais, 1:138-140

Philpotts A.R. 1977. Archean variolites- quenched immiscible liquids: Discussion. Canadian Journal of Earth Sciences, 14:139-144

Schorscher H.D. 1976. Polimetamorfismo do Pre-Cambriano na Região de Itabira, Minas Gerais. In: SBG, Congresso Brasileiro de Geologia, 29, Ouro Preto, Abstracts, 194195

Schorscher H.D. 1978. Komatiftos na estrutura "Greenstone Belt" Serie Rio das Velhas, Quadrilátero Ferrífero, Minas Gerais, Brasil. In: SBG, Congresso Brasileiro de Geologia, 30, Recife, Abstracts, 292-293

Schrank A., Souza Filho C.R., Roig H.L. 1990. Novas observações sobre as rochas ultramaficas do Grupo Quebra Osso e Formacão Córrego dos Boiadeiros, "Greenstone Belt" Rio das Velhas (MG). Cademos IG/UNICAMP, 1:6-29

Sichel S.E. 1983. Geologia das rochas pre-cambrianas da Região de Barão de Cocais e geoquimica preliminar dos komatiitos do Supergrupo Rio das Velhas, Quadrilátero Ferrifero, $M G$. Universidade Federal do Rio de Janeiro, Rio de Janeiro, M. Sc. Dissertation, $232 \mathrm{p}$.

Silva L.C. da 1996. Petrologia e Litogeoquímica. In: CPRM. Projeto. Rio das Velhas: Texto Explicativo do Mapa Geologico Integrado, escala 1:100.000. Belo Horizonte, DNPM/CPRM, 55-104

Silva L.C. da 1998. Petrologia e Litogeoquímica. In: M. Zucchetti \& 0. F. Baltazar (org.). Projeto Rio das Velhas: Texto Explicativo do Mapa Geologico Integrado, escala 1:100.000, 2 ed. Belo Horizonte, DNPM/CPRM, 55-103

Vieira F.W.R. 1991. Petrologia e litogeoqufmica do setor W do Greenstone Belt Rio das Velhas, MG. In: Simp. Int. Min., 1, e Simp. Int. Geol., 1, Nova Lima, Grupo AMSA, 130-154

Vieira F.W.R. \& Oliveira G.A.I. 1988. Geologia do Distrito Aunúfero de Nova Lima, Minas Gerais. In: C. Schobbenhaus \& C.E.S. Coelho (coord.) Principals Depósitos Minerats do Brasil. Brasilia, DNPM/CVRD, 3:377-391

Zucchetti M. 1998. Geoquimica dos Metabasaltos do Grupo Nova Lima, Greenstone Belt Rio das Velhas, Quadrilátero Ferrifero, Minas Gerais. Universidade Federal de Rio das Velhas, Quadrilatero Ferrifero, Minas Gerais.
Minas Gerais, Belo Horizonte, M. Sc. Dissertation, $97 \mathrm{p}$.

Zucchetti M., Baltazar O.F, Raposo P.O. 1996. Estratigrafia. In: CPRM. Projeto Rio das Velhas: Texto Explicativo do Mapa Geologico Integrado, escala 1:100.000. Belo Horizonte, DNPM/CPRM, 13-42

Zucchetti M., Baltazar O.F., Raposo P.O. 1998a. Estratigrafia. In: M. Zucchetti \& 0. F. Baltazar (org.). Projeto Rio das Velhas: Texto Explicativo do Mapa Geologico Integrado, escala 1:100.000,2 ed. Belo Horizonte, DNPM/CPRM, 13-42

Zucchetti M., Lobato L.M., Baars F.J. 1998b. Geoquímica dos Metabasaltos do Grupo Nova Lima, Greenstone Belt Rio das Velhas, Quadrilátero Ferrífero, Minas Gerais. In: SBG, Congresso Brasileiro de Geologia, 40, Belo Horizonte, Anais, 60

Zucchetti M. \& Lobato L. M. 1999 Feições primárias em rochas vulcanicas e vulcanoclasticas arqueanas - Greenstone Belt Rio das Velhas - MG. In: SBG, Simpósio sobre Vulcanismo e Ambientes Associados, 1, Gramado, Boletim de Resumos, 69 